\title{
Plant Growth Modulates Metabolites and Biological Activities in Retama raetam (Forssk.) Webb
}

\author{
Mariem Saada ${ }^{1}$, Hanen Falleh ${ }^{1}$, Marcelo D. Catarino ${ }^{2}$, Susana M. Cardoso ${ }^{2}$ (i) \\ and Riadh Ksouri ${ }^{1, *}$ \\ 1 Laboratory of Aromatic and Medicinal Plants, Biotechnology Center of Borj-Cédria, BP 901, \\ Hammam-lif 2050, Tunisia; saadamariem@gmail.com (M.S.); hanenfalleh@gmail.com (H.F.) \\ 2 Department of Chemistry \& Organic Chemistry, Natural Products and Food Stuffs Research Unit (QOPNA), \\ University of Aveiro, 3810-193 Aveiro, Portugal; mcatarino@ua.pt (M.D.C.); susanacardoso@ua.pt (S.M.C.) \\ * Correspondence: ksouri.riadh@gmail.com; Tel.: +216-7941-0302; Fax: +216-7941-2638
}

Received: 20 July 2018; Accepted: 24 August 2018; Published: 29 August 2018

check for updates

\begin{abstract}
This work focuses on the variability of Retama raetam (Forssk.) Webb bioactive compounds as a function of the plant cycle. The main results showed that it exhibited the highest percentage of polyunsaturated fatty acids, along with superior levels of vitamin $C$ and total phenolic compounds $\left(66.49 \%, 645.6 \mathrm{mg} \cdot 100 \mathrm{~g}^{-1} \mathrm{FW}\right.$ and $23.9 \mathrm{mg}$ GAE$\cdot \mathrm{g}^{-1}$, respectively) at the vegetative stage. Instead, at the flowering and mature fruiting stages, $R$. raetam (Forssk.) Webb exhibited notable contents of proline $\left(25.4 \mu \mathrm{mol} \cdot \mathrm{g}^{-1} \mathrm{DW}\right)$ and carotenoids $\left(27.2 \mu \mathrm{g} \cdot \mathrm{g}^{-1} \mathrm{FW}\right)$, respectively. The gathered data concerning the antioxidant activity highlighted the effectiveness of the vegetative stage in comparison to the other periods. Actually, $\mathrm{IC}_{50}$ and $\mathrm{EC}_{50}$ values of the hydromethanolic extract obtained from the plant shoots at the vegetative stage were of $23,380,410,1160$ and $960 \mu \mathrm{g} \cdot \mathrm{mL}^{-1}\left(\mathrm{DPPH}^{\bullet}\right.$ and $\mathrm{ABTS}^{\bullet+}$ radicals scavenging activity, reducing power, chelating power and $\beta$-carotene bleaching activity, respectively). Furthermore, the four studied stages showed appreciable antibacterial capacities against human pathogens with a higher efficiency of the vegetative stage extract. Finally, the LC-DAD-ESI/MS ${ }^{\mathrm{n}}$ analysis revealed the predominance of isoflavonoids as main class of phenolic compounds and demonstrates that individual phenolic biosynthesis was clearly different as a function of plant growth. These findings highlight that reaching the optimum efficiency of $R$. raetam (Forssk.) Webb is closely linked to the physiological stage.
\end{abstract}

Keywords: Retama raetam; physiological stage; lipophilic and hydrophilic compounds; GC-MS; LC-DAD-ESI $/ \mathrm{MS}^{\mathrm{n}}$; biological activities

\section{Introduction}

Antioxidants, i.e., molecules that decelerate or prevent oxidation by impairing the oxidation chain reactions, can be classified in hydrophilic and hydrophobic compounds, according to their polarity [1]. In general, water-soluble antioxidants react with oxidants in the cell cytoplasm and the blood plasma, while lipid-soluble antioxidants protect cell membranes from lipid peroxidation [2]. These compounds may be biosynthesized or obtained from the diet. Notably, antioxidants have a wide range of applications, particularly as food additives and health-promoting ingredients in the formulations of functional foods and nutraceuticals, among others [3].

Plants are good sources of bioactive compounds, including lipophilic antioxidants, such as tocopherols, carotenoids, and unsaturated fatty acids, as well as hydrophilic antioxidants, including ascorbic acid and phenolic compounds. These bioactive compounds exhibit beneficial effects such as antioxidant activity, inhibition or induction of enzymes, inhibition of receptor activities, and induction and inhibition of gene expression [4-6]. 
The antioxidant levels of plants are, however, dependent on various factors, including their growth phase. According to Lisiewska et al. [7], the phenolic content in higher plants may reflect their physiological status and developmental stages. In turn, physiological stages of the plant are closely related to climatic conditions. For instance, high exposure to sunlight in summer interferes in the biosynthesis of both primary and secondary metabolites [8]. Phenolic biosynthesis is enhanced by light, and flavonoid formation is absolutely light dependent and its biosynthetic rate is related to light intensity and density [9]. In the same context, different shade levels have been shown to affect the morphological and physiological characteristics of Hypericum perforatum, as well as its secondary metabolite (e.g., phenolic compounds) contents [10].

Retama raetam (Forssk.) Webb is a perennial shrub used in traditional medicine for the treatment of several diseases such as diabetes, hepatitis, jaundice, sore throat, skin diseases, joint pain, rheumatism, fever, inflammation, eczema, and microbial infections [11,12]. The plant is also used in Tunisia as a remedy against snake bites [13]. Research undertaken on genus Retama showed that aqueous extracts from $R$. raetam (Forssk.) Webb shoot exhibited diuretic and hypoglycemic effects [14]. Besides, shoot extracts reduced the concentration of triglycerides in the rats' plasma and significantly decreased their weight [14]. Moreover, recent works showed the antimicrobial and antioxidant capacities of Retama raetam essential oils and its interesting potential use in the food and pharmaceutical industries $[15,16]$. In addition, the previous study of our group highlighted the antioxidant and antimicrobial capacities of this species [17]. To improve the exploitation of this halophyte, the aim of this work is to further understand the changeability of lipophilic (fatty acids, carotenoids) and hydrophilic (ascorbic acid, proline, and phenolic compounds) antioxidants, as well as their biological activities (antioxidant and antimicrobial), of $R$. raetam (Forssk.) Webb during its growth cycle, which include vegetative, flowering, fresh fruiting, and mature fruiting stages (Figure 1).

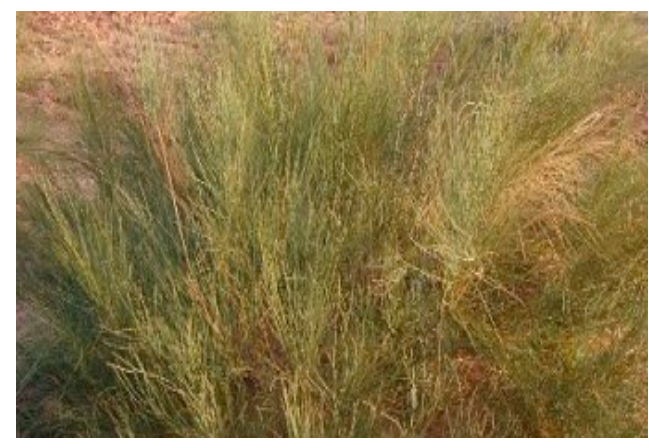

(a)

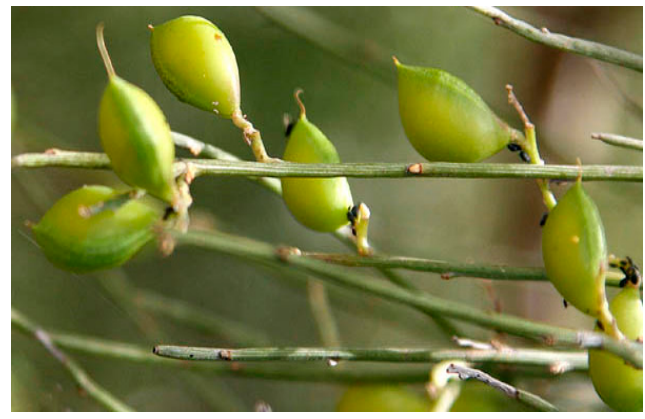

(c)

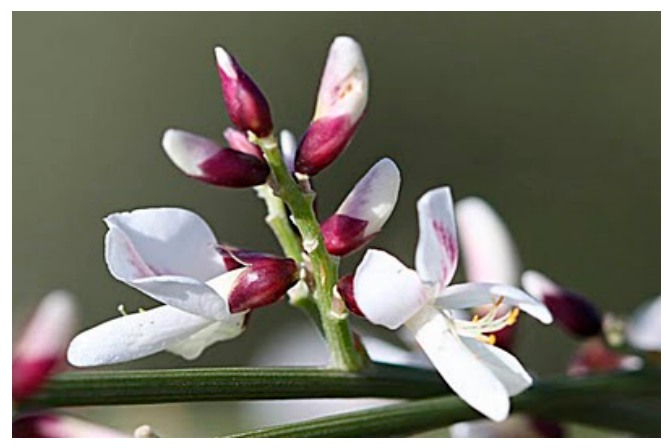

(b)

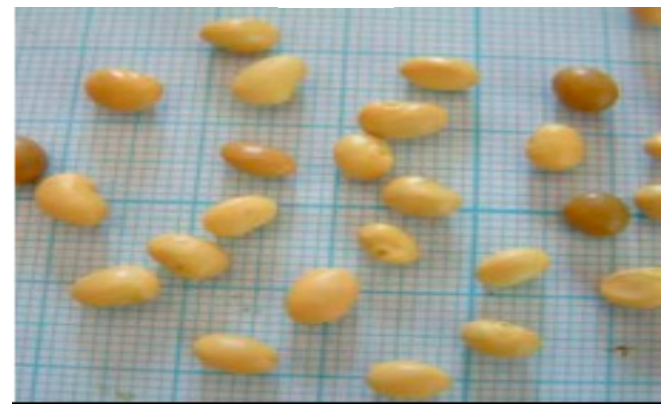

(d)

Figure 1. R. raetam (Forssk.) Webb different growth stages: aerial parts of the plant at the vegetative stage (a) and details from reproductive stages, namely flowers at the flowering stage (b), green fruits at fresh fruiting stage (c), and mature fruits at mature fruiting stage $(\mathbf{d})$. 


\section{Results and Discussion}

\subsection{Lipophilic Compounds}

The total carotenoid contents varied significantly from 2.67 to $27.19 \mu \mathrm{g} \cdot \mathrm{g}^{-1} \mathrm{FW}$, with the minimum and maximum levels being registered in the fresh and mature fruiting stages, respectively (Table 1). Note that the superior concentration of carotenoids in mature fruits compared to immature ones has been previously reported for other plants species, e.g., Howard et al. [18] demonstrated that the content of $\beta$-carotene and $\beta$-cryptoxanthin were raised from $0.02 \mu \mathrm{g} \cdot \mathrm{g}^{-1} \mathrm{FW}$ to $3.4 \mu \mathrm{g} \cdot \mathrm{g}^{-1} \mathrm{FW}$ along pepper maturation. It is possible that the carotenoids richness in $R$. raetam (Forssk.) Webb mature fruiting stage is partly associated with the involvement of these secondary metabolites in seed dispersion and therefore plant perpetuation [19].

Table 1. Carotenoids ( $\mu \mathrm{g} \cdot \mathrm{g}^{-1} \mathrm{FW}$ ) and fatty acid composition (relative \%) in shoots of Retama raetam (Forssk.) Webb at different grown stages.

\begin{tabular}{|c|c|c|c|c|}
\hline & Vegetative Stage & Flowering Stage & Fresh Fruiting Stage & Mature Fruiting Stage \\
\hline $\begin{array}{l}\text { Carotenoids }\left(\mu \mathrm{g} \cdot \mathrm{g}^{-1} \mathrm{FW}\right) \\
\text { Fatty acids (relative \%) }\end{array}$ & $16.67 \pm 0.02^{b}$ & $9.72 \pm 0.03^{c}$ & $2.67 \pm 0.02^{d}$ & $27.19 \pm 0.06^{\mathrm{a}}$ \\
\hline \multicolumn{5}{|l|}{ Saturated } \\
\hline Lauric acid C12:0 & $3.68 \pm 0.18^{\mathrm{a}}$ & $2.36 \pm 0.12^{b}$ & - & $0.04 \pm 0.00^{c}$ \\
\hline Myristic acid C14:0 & $1.51 \pm 0.07^{\mathrm{a}}$ & $1.13 \pm 0.05^{\mathrm{a}}$ & - & $0.16 \pm 0.01^{b}$ \\
\hline Pentadecylic acid C15:0 & - & - & $25.38 \pm 1.27^{\mathrm{a}}$ & $0.08 \pm 0.00^{b}$ \\
\hline Palmitic acid C16:0 & $19.10 \pm 0.95^{b}$ & $20.52 \pm 1.02^{\mathrm{a}}$ & $12.2 \pm 0.61^{\mathrm{c}}$ & $12.23 \pm 0.61^{\mathrm{c}}$ \\
\hline Margaric acid C17:0 & $0.52 \pm 0.02^{b}$ & - & - & $1.28 \pm 0.06^{\mathrm{a}}$ \\
\hline Stearic acid C18:0 & $3.66 \pm 0.18^{b}$ & $4.63 \pm 0.23^{a}$ & $2.39 \pm 0.12^{c}$ & $4.14 \pm 0.11^{\mathrm{a}}$ \\
\hline Arachidic acid C20:0 & - & $6.10 \pm 0.30^{\mathrm{a}}$ & - & $0.5 \pm 0.21^{b}$ \\
\hline Heneicosanoic acid C21:0 & - & $1 \pm 0.05$ & - & - \\
\hline $\begin{array}{c}\text { Behenic acid C22:0 } \\
\text { Unsaturated }\end{array}$ & $2.24 \pm 0.11^{\mathrm{a}}$ & - & - & $0.18 \pm 0.01^{b}$ \\
\hline Oleic acid C18:1 & - & - & - & $24.97 \pm 1.25$ \\
\hline Linoleic acid C18:2 & $22.72 \pm 1.13^{b}$ & $18.80 \pm 0.94^{c}$ & $18.75 \pm 0.94^{\mathrm{c}}$ & $49.85 \pm 2.49^{a}$ \\
\hline$\alpha$-linolenic acid C18:3 & $43.77 \pm 2.18^{b}$ & $45.37 \pm 2.26^{\mathrm{a}}$ & $38.67 \pm 1.93^{c}$ & $3.99 \pm 0.19^{d}$ \\
\hline SFA & $30.71 \pm 1.53^{c}$ & $34.74 \pm 1.74^{b}$ & $39.97 \pm 1.99^{a}$ & $18.61 \pm 0.93^{\mathrm{d}}$ \\
\hline MUFA & - & - & - & $24.97 \pm 1.25$ \\
\hline PUFA & $66.49 \pm 3.32^{\mathrm{a}}$ & $64.17 \pm 3.02^{b}$ & $57.42 \pm 2.87^{c}$ & $53.84 \pm 2.69^{d}$ \\
\hline
\end{tabular}

SFA—saturated fatty acids; MUFA—-monounsaturated fatty acids; PUFA—polyunsaturated fatty acids. Mean values \pm S.D.; Statistical analysis was performed by one-way ANOVA, followed by Duncan test. In each line different letters mean significant differences $(p<0.05)$.

The fatty acid profile of $R$. raetam (Forssk.) Webb also varied as a function of the plant grown cycle, both qualitatively and quantitatively. Indeed, while the fat portion of mature fruit plants contained eleven fatty constituents, those of the vegetative and flowering stages were composed of eight, while only five were detected at the fresh fruiting stage. Regardless, palmitic acid (C16:0) and linoleic acid (C18:2) were major representative fatty acid at all plant stages. Additionally, $\alpha$-linolenic acid (C18:3) was also a main fatty component in vegetative, flowering, and fresh fruiting stages (39-45 relative \%). In turn, the mature fruiting stage was undoubtedly the most distinguishable in terms of fatty acid composition, due to the unique presence of oleic acid (C18:1), which was absent in the other physiological phases. Overall, this stage was characterized by the lowest content of saturated fatty acids (19\% versus $31-40 \%$ ) and a high representativeness of unsaturated fatty acids, composed of MUFA ( $25 \%$ versus undetected) and PUFA (54\% versus 57-66\%). Note that according to Richard et al. [20], there is generally a significant increase in the total content of mono-unsaturated fatty acids and a decrease in poly-unsaturated fatty acids during the plant growth until fruit ripening. Changeability in fatty acid content and composition may be related to the seasonal variation of temperature and light. Accordingly, various seaweeds from cold environments have higher degree of unsaturation compared to others from warm environments [21]. This is possibly an environmental acclimatization, since PUFAs have a lower melting point than SFAs and therefore provide a physiological advantage 
in cold environments by increased membrane lipid fluidity [22]. As mentioned above, the climatic conditions corresponding to $R$. raetam (Forssk.) Webb development varies from hot and sunny weather (vegetative stage) to cold and shady climate (reproductive stages), justifying the variability between the main classes of fatty acids.

Based on fatty acid composition, the results obtained from PCA (Figure 2) clearly distinguished the existence of one well-defined group represented by the vegetative and flowering stages. These two periods presented almost the same percentage in saturated (31\% and $35 \%$, respectively) and polyunsaturated fatty acids ( $66 \%$ and $64 \%$, respectively). However, fresh and mature fruiting stages were distinguished from the former group, since in each of these two stages (fresh and mature fruiting stages) new fatty acids were detected, discriminating them from the other periods.

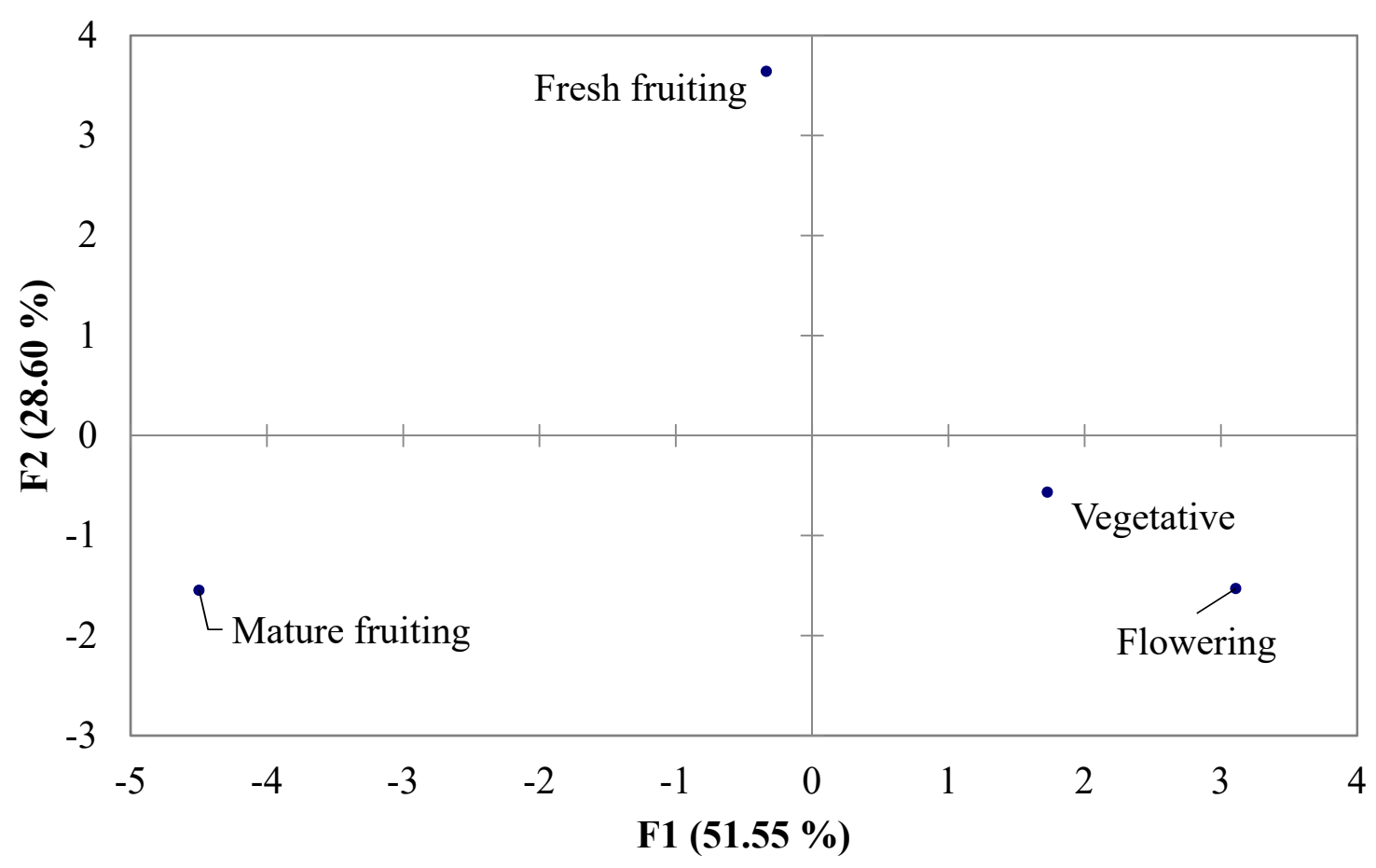

Figure 2. Principal components analysis of different stages based on the fatty acid composition of Retama raetam (Forssk.) Webb (Table 1 ).

\subsection{Hydrophylic Compounds}

Ascorbic acid (vitamin C) is an abundant component of plants that acts as a major redox buffer and as a cofactor for enzymes involved in regulating photosynthesis, hormone biosynthesis, and regenerating other antioxidants [23]. Its reduced form is the active one, and the increment in the proportion of oxidized ascorbic acid at the expense of the reduced form reflects an overexploitation of the latter for ROS detoxification [24].

As shown in Table 2, the levels of total (T-AA), reduced (R-AA), and oxidized ascorbic acid (O-AA) in $R$. raetam (Forssk.) Webb varied significantly along the plant growth cycle, being particularly high at the vegetative and flowering stages. Notably, at the vegetative stage, T-AA amounted for $645.61 \mathrm{mg} \cdot 100 \mathrm{~g}^{-1} \mathrm{FW}$, from which about $73 \%$ was in the oxidized form. This can probably be ascribed to the high exposition of the plant to sunlight during this stage, since ascorbic acid accumulation represents an important protective defense against sunlight cell damage [25]. 
Table 2. Contents of ascorbic acid, proline, and total phenolic compounds (TPC) of Retama raetam (Forssk.) Webb shoots at different grown stages.

\begin{tabular}{|c|c|c|c|c|}
\hline & Vegetative Stage & Flowering Stage & Fresh Fruiting Stage & Mature Fruiting Stage \\
\hline \multicolumn{5}{|l|}{ Vitamin C (mg.100g $\left.\mathrm{g}^{-1} \mathrm{FW}\right)$} \\
\hline Total AA & $645.61 \pm 0.15^{\mathrm{a}}$ & $627 \pm 0.18^{b}$ & $367 \pm 0.17^{c}$ & $103.2 \pm 0.00^{\mathrm{d}}$ \\
\hline Reduced AA & $173.2 \pm 0.01^{\mathrm{b}}$ & $184.5 \pm 0.01^{\mathrm{a}}$ & $130.6 \pm 0.03^{c}$ & $101.2 \pm 0.00^{\mathrm{d}}$ \\
\hline Oxidized AA & $472.45 \pm 0.01^{\mathrm{a}}$ & $442.51 \pm 0.05^{b}$ & $236.27 \pm 0.07^{c}$ & $2.01 \pm 0.06^{\mathrm{d}}$ \\
\hline Proline $\left(\mu \mathrm{mol} \cdot \mathrm{g}^{-1} \mathrm{DW}\right)$ & $12.1 \pm 0.03^{b}$ & $25.4 \pm 0.01^{\mathrm{a}}$ & $11.23 \pm 0.01^{\mathrm{c}}$ & $1.56 \pm 0.01^{\mathrm{d}}$ \\
\hline TPC (mg GAE $\left.\cdot g^{-1} \mathrm{DW}\right)$ & $23.93 \pm 0.03^{a}$ & $20.75 \pm 0.02^{b}$ & $18.23 \pm 0.02^{b}$ & $15.17 \pm 0.02^{\mathrm{c}}$ \\
\hline
\end{tabular}

Mean values \pm S.D.; Statistical analysis was performed by one-way ANOVA, followed by Duncan test. In each line, different letters mean significant differences $(p<0.05)$.

In turn, proline (i.e., amino acid that might modulate oxidative stress tolerance in plants) reached its maximum levels at the flowering period $\left(25.4 \mu \mathrm{mol} \cdot \mathrm{g}^{-1} \mathrm{DW}\right)$, while its amounts decreased by about half at the vegetative and fresh fruiting periods (11-12 $\left.\mu \mathrm{mol} \cdot \mathrm{g}^{-1} \mathrm{DW}\right)$ and to more than $90 \%$ at the mature fruiting stage. Possibly, the abundance of this compound in the flowering stage might be associated with its relevance in the stimulation of the flowering process [26]. In this regard, Lehmann et al. [27] reported that proline induces precocious flowering and enhances the formation of axillary flower buds. In addition, proline is a major constituent of pollen, where it can represent up to $70 \%$ of total free amino acids, and nectar [27]. The highest levels of proline in the flowering stage, as compared to the mature fruiting and the vegetative periods, has also been described by Kale [28] for the medicinal plant Microphyllus convolvulus.

The total phenolic content of the $R$. raetam (Forssk.) Webb also varied considerably among the four growth stages. This was maximum during the vegetative phase $\left(23.93 \mathrm{mg} \mathrm{GAE} \cdot \mathrm{g}^{-1} \mathrm{DW}\right)$ and decreased progressively until the mature fruiting phase, reaching $15.17 \mathrm{mg} \mathrm{GAE} \cdot \mathrm{g}^{-1} \mathrm{DW}$ (Table 2). Changes in phenolic compounds as a function of plant physiological stage has already been discussed by other researchers. For instance, Ksouri et al. [29] registered the highest polyphenols contents of the halophyte Salsola kali at the vegetative period, while minimum values were observed at the flowering stage (17 and $5 \mathrm{mg} \mathrm{GAE} \cdot \mathrm{g}^{-1} \mathrm{DW}$, respectively). In this context, one should highlight that the fruit maturation process implies an important amplification of the activity of polyphenol oxidase (PPO), resulting in a notable degradation of total polyphenols from the vegetative stage to the mature fruiting one [30]. Moreover, environmental factors can also contribute for such differences, since according to the Tunisian national institute of meteorology, during the vegetative period (June-December), R. raetam (Forssk.) Webb was exposed to a media of 329 insolation hours per month, while this was about half for the reproductive stages. This is consistent to the general concept that phenolic compounds play a UV-protective role in the plants [25]. In this respect, Combris et al. [31] and Toor et al. [32] reported that UV rays associated with increased solar radiation stimulated phenolic metabolism and their concomitant accumulation in the plant, especially in its aerial organs.

In addition to the changes in the total phenolic amounts, our results also showed noticeable variations on the individual phenolic components of the plant along its growth cycle (Figure 3 and Table 3). Notably, the UHPLC-DAD-ESI/MS ${ }^{\mathrm{n}}$ chromatogram of the hydromethanolic extracts obtained from $R$. raetam (Forssk.) Webb showed a high predominance of isoflavones. Overall, with exception of the extract from the mature fruiting, the phenolic profile of the extracts revealed close resemblances to each other, although great differences in peak intensities were noticeable. Among them, extracts from the vegetative and fresh fruiting stages were very similar, both being characterized by two major peaks corresponding to genistein-8-C-hexoside (peak $7, \lambda_{\max }$ at $261 \mathrm{~nm},[\mathrm{M}-\mathrm{H}]^{-}$at $m / z 431$ ), which accounted for $888.53 \pm 24.57$ and $628.19 \pm 10.68 \mu \mathrm{g} / \mathrm{g}$ DW, respectively, and to an unknown compound (peak 15, $\lambda_{\max }$ at $282 \mathrm{~nm},[\mathrm{M}-\mathrm{H}]^{-}$at $m / z 311$ ). The extract from the flowering stage showed the highest diversity of phenolic compounds, with genistein-7-O-glucoside, i.e., genistin (peak 10, $\lambda_{\max }$ at $260 \mathrm{~nm},[\mathrm{M}-\mathrm{H}]^{-}$at $m / z$ 477) becoming the most abundant compound, reaching a concentration of $867.17 \pm 44.21 \mu \mathrm{g} / \mathrm{g}$ DW, alongside with genistein-8-C-hexoside that amounted 
for $571.74 \pm 60.94 \mu \mathrm{g} / \mathrm{g}$ DW. Additionally, genistein (peak 14, $\lambda_{\max }$ at $261 \mathrm{~nm},[\mathrm{M}-\mathrm{H}]^{-}$at $m / z 269$ ) and the flavone apigenin-7-O-glucoside (peak 12, $\lambda_{\max }$ at 267 and $336 \mathrm{~nm},[\mathrm{M}-\mathrm{H}]^{-}$at $m / z 431$ ) also appeared as relevant compounds in this extract.
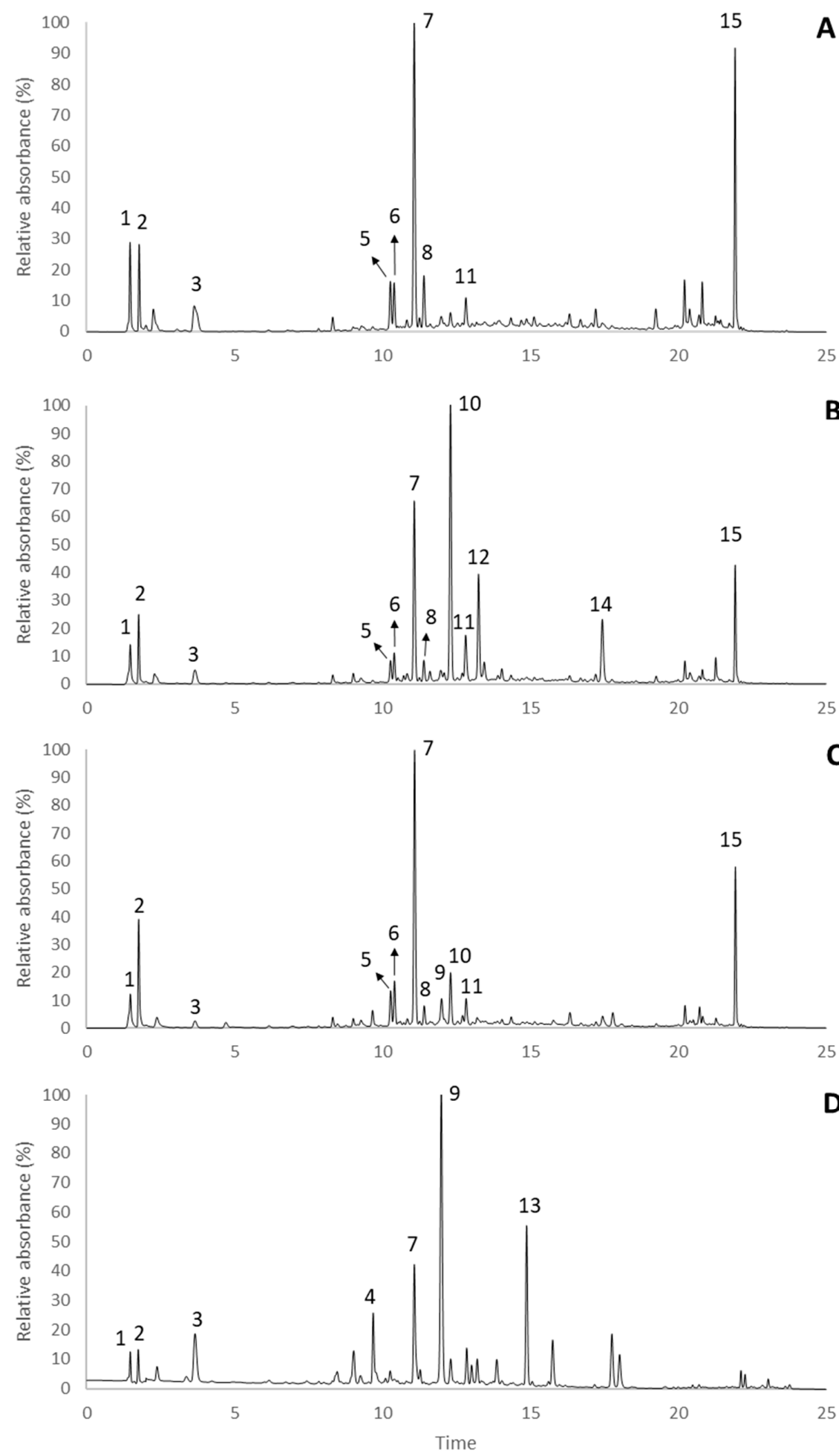

Figure 3. Chromatographic profiles of R. raetam (Forssk.) Webb hydromethanolic extracts from different seasons: (A) vegetative; (B) flowering; (C) fresh fruiting; and (D) mature fruiting stages recorded at $280 \mathrm{~nm}$. Peak numbers correspond to those represented in Table 3. 
Table 3. Identification and quantification of the main compounds from the four R. raetam (Forssk.) Webb stages by UHPLC-DAD-ESI/MSn .

\begin{tabular}{|c|c|c|c|c|c|c|c|c|c|}
\hline \multirow[b]{2}{*}{ Peak } & \multirow[b]{2}{*}{ RT (min) } & \multirow[b]{2}{*}{$\lambda_{\max }(\mathrm{nm})$} & \multirow[b]{2}{*}{$\begin{array}{c}{[\mathrm{M}-\mathrm{H}]^{-}} \\
(\mathrm{m} / \mathrm{z})\end{array}$} & \multirow[b]{2}{*}{ ESI-MS ${ }^{\mathrm{n}}$ Fragments } & \multirow[b]{2}{*}{ Proposed Compounds } & \multicolumn{4}{|c|}{ Mean Content ( $\mu \mathrm{g} / \mathrm{g}$ Dry Plant Material) } \\
\hline & & & & & & $\begin{array}{l}\text { Vegetative } \\
\text { Stage }\end{array}$ & $\begin{array}{c}\text { Flowering } \\
\text { Stage }\end{array}$ & $\begin{array}{c}\text { Fresh Fruiting } \\
\text { Stage }\end{array}$ & $\begin{array}{c}\text { Mature } \\
\text { Fruiting Stage }\end{array}$ \\
\hline 1 & 1.45 & 303 & 133 & $\mathrm{MS}^{2}$ [133]: 115 & Malic acid & + & + & + & + \\
\hline 2 & 1.74 & 227,304 & 191 & 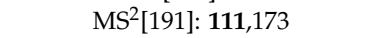 & Citric acid & + & + & + & + \\
\hline 3 & 3.63 & 223,275 & 255 & $\mathrm{MS}^{2}[255]: 165,193,179,149$ & Piscidic acid & + & + & + & + \\
\hline 4 & 9.68 & 271,334 & 593 & $\operatorname{MS}^{2}[593]: 473,503,353,383,575$ & Vicenin 2 & ND & ND & tc & + \\
\hline 5 & 10.26 & 255 & $491^{*}$ & $\begin{array}{l}\operatorname{MS}^{2}[491]: 283,445 ; \\
\operatorname{MS}^{3}[283]: \mathbf{2} 268\end{array}$ & Calycosin-O-hexoside & + & + & + & ND \\
\hline 6 & 10. 39 & 261 & 563 & $\operatorname{MS}^{2}[563]: 311,283,341,269$ & Genistein- $C$-hexoside-O-pentoside & + & + & + & ND \\
\hline 7 & 11.07 & 261 & 431 & $\mathrm{MS}^{2}$ [431]: 311, 269 & Genistein-8-C-hexoside & $888.53 \pm 24.57^{a}$ & $571.74 \pm 60.94^{\mathrm{c}}$ & $628.19 \pm 10.68^{b}$ & + \\
\hline 8 & 11.93 & 262 & 461 & $\mathrm{MS}^{2}[461]: 341,371$ & Tectorigenin-8-C-hexoside & + & + & + & ND \\
\hline 9 & 11.98 & 289 & 303 & $\begin{array}{c}\operatorname{MS}^{2}[303]: \mathbf{2 8 5}, 177,125 \\
\operatorname{MS}^{3}[285]: 241,175,257,199,217\end{array}$ & Taxifolin & ND & ND & + & $224.92 \pm 4.03$ \\
\hline 10 & 12.30 & $260, \operatorname{sh} 325$ & $477^{*}$ & $\mathrm{MS}^{2}[477]: 269,311$ & Genistin & tc & $867.17 \pm 44.21$ & + & ND \\
\hline 11 & 12.82 & $262, \operatorname{sh} 324$ & 575 & $\mathrm{MS}^{2}$ [575]: $431,311,341$ & Genistein-3-hydroxy-3-methylglutaroyl & + & + & + & tc \\
\hline 12 & 13.24 & 267,336 & 431 & $\mathrm{MS}^{2}[431]: \mathbf{2 6 9}$ & Apigenin-7-O-glucoside & ND & + & ND & ND \\
\hline 13 & 14.87 & 231,307 & 805 & $\begin{array}{c}\mathrm{MS}^{2} \text { [805]: 497, 351; } \\
\text { MS }^{3} \text { [497]: 145, 351, } 333\end{array}$ & $p$-Coumaric acid derivative & ND & ND & ND & + \\
\hline 14 & 17.43 & $261, \operatorname{sh} 331$ & 269 & $\operatorname{MS}^{2}[269]: \mathbf{2 6 9}, 225,241$ & Genistein & ND & + & ND & ND \\
\hline 15 & 22.40 & 282 & 311 & $\mathrm{MS}^{2}[311]: \mathbf{2 4 9}, 293$ & Unkown & + & + & + & ND \\
\hline
\end{tabular}
tc, traces; ND, not detected; + , detected but not quantified; ${ }^{*}$, detected as $[\mathrm{M}-\mathrm{H}+\mathrm{HCOOH}]^{-}$adducts. Mean values \pm S.D.; Statistical analysis was performed by one-way ANOVA,
followed by Duncan test. In each line different letters mean significant differences $(p<0.05)$. 
Interestingly, a clear change of the phenolic profile was noticed in the mature fruiting stage of the plant, which was characterized by the predominance of the flavanonol taxifolin (peak $9, \lambda_{\max }$ at $289 \mathrm{~nm},[\mathrm{M}-\mathrm{H}]^{-}$at $\left.m / z 303\right)$, the glycosylated flavone apigenin-6,8-O-diglucoside, i.e., vicenin 2 (peak 4, $\lambda_{\max }$ at 271 and $334 \mathrm{~nm},[\mathrm{M}-\mathrm{H}]^{-}$at $m / z 593$ ) and a phenolic acid (peak 13, $\lambda_{\max }$ at 231 and $307 \mathrm{~nm},[\mathrm{M}-\mathrm{H}]^{-}$at $m / z$ 805) that was tentatively assigned to a $p$-coumaric acid derivative, since its MS fragmentation pattern showed a MS ${ }^{2}$ product ion at $m / z 497$ (equivalent to the loss of a rutinose moiety), and further $\mathrm{MS}^{3}$ fragments at $m / z 145$ (indicating a coumaroyl moiety), $351\left([\mathrm{M}-\mathrm{H}-146]^{-}\right.$) and $333\left([\mathrm{M}-\mathrm{H}-164]^{-}\right)$. Moreover, the major unknown compound detected in the remaining growth stages (peak 15) was completely absent in the mature fruit extract. This outcome suggests that the fruit maturation process has great impact on the phenolic profile of $R$. raetam (Forssk.) Webb. Indeed, in Touati et al. [33], taxifolin was detected in considerable amounts in grains but not in the stems of $R$. sphaerocarpa, which confirms that this flavanonol is only biosynthesized in the fruits, therefore explaining its presence in the mature fruiting extracts but not in the others.

Note that previous studies showed that isoflavonoid glucosides are common in Retama genus [34]. In fact, isoflavones such as genistein, genistin, daidzin, daidzein, biochanin A, $6^{\prime}$-methoxypseudobaptegenin, and puerarin have been isolated and identified from $R$. sphaerocarpa, R. monosperma, and R. raetam [34,35]. Concerning R. raetam, previous phytochemical studies resulted in the isolation of a number of compounds, with the most characteristic corresponding to flavonoids and alkaloids. Flavonoids such as daidzein, vicenin-2, naringenin, apigenin, kaempferol, quercetin, and kaempferol-7-O-glucoside were found in the seeds [36], while daidzein 7,4'-dimethyl ether, chrysoeriol 7-O-glucoside, and orientin were isolated from the leaves [36]. In addition, Kassem et al. [36] described the occurrence of two new flavonoids in the aerial parts of the plant, namely luteolin $4^{\prime}$-O-neohesperidoside and 5,4'-dihydroxy-( $3^{\prime \prime}, 4^{\prime \prime}$-dihydro$3^{\prime \prime}, 4^{\prime \prime}$-dihydroxy)-2", $2^{\prime \prime}$-dimethylpyrano-( $\left.5^{\prime \prime}, 6^{\prime \prime}: 7,8\right)$-flavone. Still, to the best of our knowledge, several of the genistein derivatives herein identified, namely genistein- $C$-hexoside- $O$-pentoside (peak 6, $\lambda_{\max }$ at $261 \mathrm{~nm},[\mathrm{M}-\mathrm{H}]^{-}$at $m / z$ 563), genistein-8-C-hexoside (peak 7) and genistein-3-hydroxy-3-methylglutaroyl (peak 11, $\lambda_{\max }$ at $262 \mathrm{~nm},[\mathrm{M}-\mathrm{H}]^{-}$at $m / z 575$ ) have never been reported in the genus Retama before, as well as tectorigenin-8-C-hexoside (peak $8, \lambda_{\max }$ at $262 \mathrm{~nm}$, $[\mathrm{M}-\mathrm{H}]^{-}$at $m / z 461$ ), apigenin-7-O-glucoside (peak 12). Compounds such as piscidic acid (peak 3, $\lambda_{\max }$ at 223 and $275 \mathrm{~nm},[\mathrm{M}-\mathrm{H}]^{-}$at $m / z$ 255), vicenin 2 (peak 4), calycosin-O-hexoside (peak $5, \lambda_{\max }$ at $255 \mathrm{~nm},[\mathrm{M}-\mathrm{H}]^{-}$at $m / z 491$ ), and genistin (peak 10) are also being reported for the first time in this species.

\subsection{Antioxidant Activities}

In this study, the antioxidant ability of the hydromethanolic extracts from $R$. raetam (Forssk.) Webb at the four growth stages was screened through in vitro methods, namely total antioxidant activity (TAA), $\mathrm{DPPH}^{\bullet} \mathrm{ABTS}^{\bullet+}$, FRAP, chelating power, and $\beta$-carotene bleaching, in order to evaluate their scavenging ability towards distinct radicals, as well as the ability to reduce $\mathrm{Fe}^{3+}$ to $\mathrm{Fe}^{2+}$, to chelate $\mathrm{Fe}^{2+}$, and to inhibit the bleaching of the antioxidant pigment $\beta$-carotene, respectively.

As shown in Table 4, with few exceptions, the antioxidant potency of the extracts could be generalized as vegetative stage $>$ mature fruiting stage $>$ fresh fruiting stage $>$ flowering stage. The dominance of the vegetative extract regarding the remaining ones varied among the assays and was particularly evident in chelating power and $\beta$-carotene bleaching tests $\left(\mathrm{IC}_{50}\right.$ values of mature fruiting and flowering/fresh fruiting were about 3-6.6 and 8-11 fold those found for vegetative stage). Note that the superior antioxidant potency of the hydromethanolic extract from vegetative stage, together with its richness in TPC, suggests that phenolic compounds might be responsible for such activity. Yet, the lower antioxidant capacity of the flowering/fresh fruiting stages (with TPC levels of $20.75 \pm 0.02$ and $18.23 \pm 0.02 \mathrm{mg} \mathrm{GAE} \cdot \mathrm{g}^{-1} \mathrm{DW}$, respectively) as compared to that of mature fruiting stage (with TPC levels of $15.17 \pm 0.02 \mathrm{mg} \mathrm{GAE} \cdot \mathrm{g}^{-1} \mathrm{DW}$ ) also suggest that non-phenolic components might also play a relevant role in the involved reactions. Interestingly, other authors also highlighted 
the antioxidant activity of plants in vegetative growth stages, as compared to other physiological periods. E.g., the total antioxidant activity of the halophyte Cakile maritima at the vegetative stage was reported by Meot-Duros et al. [37], while Ksouri et al. [29] showed the same tendency when evaluating $\mathrm{DPPH}^{\bullet}$ scavenging activity of Salsola kali shoots.

Table 4. Total antioxidant activity (TAA), $\mathrm{DPPH}^{\bullet}$ test, $\mathrm{ABTS}^{\bullet+}$ assay, reducing power, chelating power and $\beta$-carotene bleaching activity) of the hydromethanolic extracts from Retama raetam (Forssk.) Webb shoots of different grown stages.

\begin{tabular}{|c|c|c|c|c|}
\hline & Vegetative Stage & Flowering Stage & Fresh Fruiting Stage & Mature Fruiting Stage \\
\hline TAA (mg GAE $\left.\cdot g^{-1} \mathrm{DW}\right)$ & $55.6 \pm 0.04^{\mathrm{a}}$ & $32.3 \pm 0.02^{c}$ & $26.02 \pm 0.02^{d}$ & $43.73 \pm 0.03^{b}$ \\
\hline $\mathrm{DPPH}^{\bullet}\left(\mathrm{IC}_{50} \mu \mathrm{g} \cdot \mathrm{mL}^{-1}\right)$ & $23 \pm 0.01^{\mathrm{a}}$ & $160 \pm 0.01^{d}$ & $68 \pm 0.00^{c}$ & $20.5 \pm 0.00^{\mathrm{b}}$ \\
\hline $\mathrm{ABTS}^{\bullet+}$ assay $\left(\mathrm{IC}_{50} \mu \mathrm{g} \cdot \mathrm{mL}^{-1}\right)$ & $380 \pm 0.02^{\mathrm{a}}$ & $940 \pm 0.01^{\mathrm{d}}$ & $780 \pm 0.00^{c}$ & $540 \pm 0.01^{b}$ \\
\hline Reducing power $\left(\mathrm{EC}_{50} \mu \mathrm{g} \cdot \mathrm{mL}^{-1}\right)$ & $410 \pm 0.00^{\mathrm{a}}$ & $2500 \pm 0.01^{\mathrm{d}}$ & $2300 \pm 0.01^{c}$ & $805 \pm 0.00^{b}$ \\
\hline Chelating power $\left(\mathrm{EC}_{50} \mu \mathrm{g} \cdot \mathrm{mL}^{-1}\right)$ & $1160 \pm 0.01^{\mathrm{a}}$ & $12,292 \pm 0.03^{d}$ & $11,933 \pm 0.00^{c}$ & $7600 \pm 0.02^{b}$ \\
\hline$\beta$-carotene bleaching $\left(\mathrm{IC}_{50} \mu \mathrm{g} \cdot \mathrm{mL}^{-1}\right)$ & $960 \pm 0.01^{\mathrm{a}}$ & $8500 \pm 0.00^{\mathrm{d}}$ & $7700 \pm 0.00^{c}$ & $3100 \pm 0.00^{b}$ \\
\hline
\end{tabular}

Mean values \pm S.D.; Statistical analysis was performed by one-way ANOVA, followed by Duncan test. In each line different letters mean significant differences $(p<0.05)$.

\subsection{Antimicrobial Activity of Shoot Extracts}

The hydromethanolic extracts of $R$. raetam (Forssk.) Webb at the four growth stages displayed distinct antimicrobial effects towards the 14 tested pathogenic bacteria strains (Table 5). The most interesting antibacterial activity was provided by the extract from the vegetative stage. This was particularly active against Bacillus cereus and Vibrio vulnificus (inhibition zone diameter of 12 and $11 \mathrm{~mm}$, respectively) but also had strong activity against the Gram-positive Listeria monocytogenes, Enterococcus faecalis, and Micrococcus luteus, as well as towards the Gram-negative Aeromonas hydrophila, Vibrio vulnificus, Vibrio alginolyticus, and Vibrio cholerae (diameter of inhibition zone between 7 and $11 \mathrm{~mm}$ ). In turn, no activity was noted against Staphylococcus epidermidis, Escherichia coli, Pseudomonas aeruginosa, Salmonella typhimurium, Staphylococcus aureus, and Vibrio parahaemolyticus.

Table 5. Antibacterial activity of Retama raetam (Forssk.) Webb shoots (at $100 \mathrm{mg} \cdot \mathrm{mL}^{-1}$ ) at different grown stages against fourteen human pathogenic bacteria.

\begin{tabular}{|c|c|c|c|c|c|}
\hline Bacterial Strains & & $\begin{array}{l}\text { Vegetative } \\
\text { Stage }\end{array}$ & $\begin{array}{c}\text { Flowering } \\
\text { Stage }\end{array}$ & $\begin{array}{c}\text { Fresh Fruiting } \\
\text { Stage }\end{array}$ & $\begin{array}{c}\text { Mature } \\
\text { Fruiting Stage }\end{array}$ \\
\hline \multicolumn{6}{|l|}{ Gram-positive } \\
\hline Bacillus cereus & ATCC 14579 & $12 \pm 0.00^{\mathrm{a}}$ & $12 \pm 0.57^{\mathrm{a}}$ & $9 \pm 0.57^{\mathrm{a}}$ & $10 \pm 1.00^{\mathrm{a}}$ \\
\hline Staphylococcus aureus & ATCC 25923 & - & - & - & - \\
\hline Staphylococcus epidermidis & CIP 106510 & - & - & - & - \\
\hline Listeria monocytogenes & ATCC 19115 & $9 \pm 0.57^{\mathrm{d}}$ & $8 \pm 0.57^{c}$ & - & $7 \pm 0.00^{\mathrm{d}}$ \\
\hline Enterococcus faecalis & ATCC 29212 & $10 \pm 0.57^{c}$ & $9 \pm 1.15^{b}$ & $8 \pm 0.00^{b}$ & - \\
\hline Micrococcus luteus & NCIMB 8166 & $9 \pm 0.57^{d}$ & $9 \pm 0.57^{b}$ & $9 \pm 0.57^{a}$ & $9 \pm 0.57^{b}$ \\
\hline \multicolumn{6}{|l|}{ Gram-negative } \\
\hline Escherichia coli & ATCC 85218 & - & - & - & - \\
\hline Pseudomonas aeruginosa & ATCC 27853 & - & - & - & - \\
\hline Salmonella typhimurium & ATCC 1408 & - & - & - & - \\
\hline Aeromonas hydrophila & ATCC 7566 & $9 \pm 0.00^{\mathrm{d}}$ & $8 \pm 0.57^{c}$ & $9 \pm 0.57^{\mathrm{a}}$ & $9 \pm 0.00^{b}$ \\
\hline Vibrio vulnificus & ATCC $27962 \mathrm{~T}$ & $11 \pm 1.15^{b}$ & $9 \pm 0.57^{b}$ & - & - \\
\hline Vibrio alginolyticus & ATCC 33787 & $9 \pm 0.57^{d}$ & $9 \pm 0.57^{b}$ & $8 \pm 0.57^{b}$ & $8 \pm 0.00^{c}$ \\
\hline Vibrio cholerae & non- $\mathrm{O}_{1}$ IPT & $9 \pm 0.00^{d}$ & $8 \pm 1.00^{c}$ & - & - \\
\hline Vibrio parahaemolyticus & ATCC 17802 & - & - & - & - \\
\hline
\end{tabular}

Inhibition zone (IZ) calculated as diameter around the disc (mm). The diameter of disc was $6 \mathrm{~mm}$. No antimicrobial activity (-), inhibition zone $<1 \mathrm{~mm}$. Weak inhibition zone, inhibition zone $1 \mathrm{~mm}$. Slight antimicrobial activity, inhibition zone 2 to $3 \mathrm{~mm}$. Moderate antimicrobial activity, inhibition zone 4 to $5 \mathrm{~mm}$. High antimicrobial activity, inhibition zone 6 to $9 \mathrm{~mm}$. Strong antimicrobial activity, inhibition zone $>9 \mathrm{~mm}$. Mean values \pm S.D.; Statistical analysis was performed by one-way ANOVA, followed by Duncan test. In each line different letters mean significant differences $(p<0.05)$. 
In general, the extract from the flowering stage also showed strong activity against the same strains (diameter of inhibition zone in the range of 7 and $12 \mathrm{~mm}$ ), while those of fresh and/or mature fruiting failed to inhibit Listeria monocytogenes, Enterococcus faecalis Vibrio vulnificus, and Vibrio cholerae. The higher activity of extracts from the vegetative and flowering stages could be ascribed to their phenolic compound richness, especially flavonoids (isoflavonoids), possibly due to their adsorption to cell membranes provoking their destabilization and/or interaction with some enzymes, substrates, or metal ion deprivation, as previously suggested [38-40].

\section{Materials and Methods}

\subsection{Plant Sampling and Extract Preparation}

Retama raetam (Forssk.) Webb samples were collected from the Sebkha of Soliman (30 km from capital of Tunis; $36^{\circ} 42^{\prime} 50^{\prime \prime} \mathrm{N}$ and $10^{\circ} 24^{\prime} 31^{\prime \prime} \mathrm{E}$; superior semi-arid bioclimatic stage; mean annual rainfall: $500-600 \mathrm{~mm}$ ) at different periods:

1- Vegetative stage: the plants, of about $2 \mathrm{~m}$ high, were collected in September 2010. The shrub had many long and velvety green twigs, jagged and covered with small silky white hairs (Figure 1a).

2- Flowering stage: the plants, of about $2 \mathrm{~m}$ high, were collected in February 2011. Their flowers (Figure $1 b$ ) were white, tiny and formed by 5 to 10 petals.

3- $\quad$ Fresh fruiting stage: the plants, of about $2 \mathrm{~m}$ high, were collected in April 2011. The green fruit (Figure 1c) was a small egg-shaped pod that ended with a beak.

4- Mature fruiting stage: the plants, of about $2 \mathrm{~m}$ high, were collected in collected in May 2011. The matured fruit (Figure 1d) contained only one kidney-shaped seed of a yellow ocher.

Plants were identified by the botanist of the Biotechnology Center of Borj-Cedria (CBBC), and a voucher specimen (F-RE 27) was deposited at the Herbarium of the Laboratory of Extremophile Plants at CBBC.

Carotenoids and vitamin $\mathrm{C}$ analysis were performed on the shoots of fresh plants, which were kept at $-80^{\circ} \mathrm{C}$ until the analysis. In turn, the remaining analyses were performed with air-dried shoots (two weeks followed by oven-dried for $1 \mathrm{~h}$ at $40^{\circ} \mathrm{C}$ ).

\subsection{Chemical Reagents}

Folin-Ciocalteu reagent, sodium carbonate anhydrous $\left(\mathrm{Na}_{2} \mathrm{CO}_{3}\right)$, gallic acid, sodium nitrite $\left(\mathrm{NaNO}_{2}\right)$, aluminum chloride hexahydrate $\left(\mathrm{AlCl}_{3}, 6 \mathrm{H}_{2} \mathrm{O}\right)$, 2,2-diphenyl-1-picrylhydrazyl $\left(\mathrm{DPPH}^{\bullet}\right)$, ninhydrin, sodium hydroxide de $(\mathrm{NaOH})$, trichloroacetic acid iron, 2,2' -pipyridyl; chloride anhydrous $\left(\mathrm{FeCl}_{3}\right)$ and catechin were purchased from Fluka (Buchs, Switzerland). ABTS single reagent, $\beta$-Carotene, Tween 40, linoleic acid, $N$-ethylmaleimide (NEM), dithiothreitol (DTT), iron dichloride $\left(\mathrm{FeCl}_{2}\right)$, and butylated hydroxytoluene $(\mathrm{BHT})$ were purchased from Sigma-Aldrich $(\mathrm{GmbH}$, Sternheim, Germany). Sulfuric acid $\left(\mathrm{H}_{2} \mathrm{SO}_{4}\right)$, potassium ferricyanide $\mathrm{K}_{3} \mathrm{Fe}(\mathrm{CN})_{6}$, glacial acetic acid, sulfosalicylic acid, ferrozine and Muller Hinton medium were purchased from Merck (Darmstadt, Germany). The phenolic standards ginestin and quercetin-7-O-galactoside were purchased from Extrasynthese (Genay, France).

\subsection{Assessment of Lipophilic Compounds}

\subsubsection{Carotenoids}

Carotenoid content was determined according to the method of Nonier et al. [41]. Two mL of $80 \%$ acetone were added to samples cut into discs (200 mg each). The extraction took place in dark at $4{ }^{\circ} \mathrm{C}$ for $72 \mathrm{~h}$, followed by absorbance measurement at 470,663, and $647 \mathrm{~nm}$. The total amount of carotenoids was then calculated through the Formula (1):

$$
\text { Carotenoids }\left(\mu \mathrm{g} \cdot \mathrm{mL}^{-1}\right)=5 \times \mathrm{A}_{(470)}+2.846 \times \mathrm{A}_{(663)}-14.876 \times \mathrm{A}_{(647)}
$$




\subsubsection{Fatty Acids}

The fatty acids profile was determined by GC/MS (Gas chromatography/mass spectrometer detector), after Soxhlet extraction of $30 \mathrm{~g}$ of dry shoots with hexane for $4 \mathrm{~h}$, followed by esterification of fat according to the previous procedure of Megdiche-Ksouri et al. [42]. In more detail, $0.2 \mathrm{~mL}$ of the lipidic extract was saponified with $3 \mathrm{~mL}$ of a methanolic sodium hydroxide solution $(0.5 \mathrm{M})$ for $15 \mathrm{~min}$ in a water bath at $60{ }^{\circ} \mathrm{C}$. The mixture was then homogenized with $3 \mathrm{~mL}$ of a methanolic solution of $\mathrm{BF}_{3}(14 \%)$ and the reaction was allowed to proceed for $5 \mathrm{~min}$. Subsequently, $2 \mathrm{~mL}$ of water were added to the mixture and fatty acids methyl esters (FAMEs) were extracted twice with $10 \mathrm{~mL}$ of petroleum ether. The GC apparatus consisted of a HP-5980 Series II instrument, equipped with HP-5MS capillary column $\left(30 \mathrm{~m} \times 0.25 \mathrm{~mm} ; 0.25 \mu \mathrm{m}\right.$ film thickness), split/splitless injector $\left(220^{\circ} \mathrm{C}\right)$. The oven temperature was held at $150{ }^{\circ} \mathrm{C}$, then programmed at $15^{\circ} \mathrm{C} / \mathrm{min}$ up to $220^{\circ} \mathrm{C}$, and held isothermally at $220^{\circ} \mathrm{C}$ for $5 \mathrm{~min}$. Helium was the carrier gas at an initial flow rate of $1 \mathrm{~mL} / \mathrm{min}$. Split ratio was 20:1. Injection volume was equal to $2 \mu \mathrm{L}$ FAMES components were identified by comparing their relative retention times and mass spectra with the data from the library Wiley, Mass-Finder, and Adams GC/MS libraries and their abundance and the results expressed in relative percentage of each fatty acid.

\subsection{Assessment of Hydrophilic Compounds}

\subsubsection{Vitamin C}

The assay used in the present study is based on the reduction of $\mathrm{Fe}^{3+}$ to $\mathrm{Fe}^{2+}$ by ascorbic acid under acidic conditions [43]. The $\mathrm{Fe}^{2+}$ forms complexes with 2,2'-pipyridyl at $4 \%$, producing a pink color that absorbs at $525 \mathrm{~nm}$. Oxidized vitamin $C$ was converted to reduced vitamin $C$ by pre-incubation of the sample with dithiothreitol (DTT, $10 \mathrm{mM}$ ). The excess of DTT was then removed with $N$-ethylmaleimide (NEM) and the reduced Vitamin C was determined. The amount of oxidized Vitamin $C$ was then calculated between total and reduced acid ascorbic.

\subsubsection{Proline}

Proline was determined following the ninhydrin method described by Bates et al. [44], using L-proline as a standard. Ten $\mathrm{mg}$ of shoot samples were homogenized in $1.5 \mathrm{~mL}$ of $3 \%$ aqueous sulfosalicylic acid and centrifuged for $30 \mathrm{~min}$ at $14,000 \times \mathrm{g}$. To the supernatant $(1 \mathrm{~mL}), 1 \mathrm{~mL}$ of acid ninhydrin and $1 \mathrm{~mL}$ of glacial acetic acid were added, and the mixture was boiled for $1 \mathrm{~h}$. After extraction with $2 \mathrm{~mL}$ of toluene, the free proline molecule was quantified at $520 \mathrm{~nm}$.

\subsubsection{Phenolic Compounds}

Total phenolic compounds and total flavonoids were measured according to the method of Dewanto et al. [45] and the results were expressed as $\mathrm{mg}$ of gallic acid or mg catechin per gram of dry weight (mg CE. $\left.\mathrm{g}^{-1} \mathrm{DW}\right)$, respectively. In addition, individual phenolic compounds were identified by UHPLC-DAD-ESI/MS ${ }^{\mathrm{n}}$ of hydromethanolic extracts $(2.5 \mathrm{~g}$ dry powder in $25 \mathrm{~mL}$ of $80 \%$ methanol, for $30 \mathrm{~min}$ ), as described elsewhere [46]. The work was carried out in Ultimate 3000 (Dionex Co., San Jose, CA, USA) apparatus with an ultimate 3000 Diode Array Detector (Dionex Co., San Jose, CA, USA) coupled to a Thermo LTQ XL (Thermo Scientific, San Jose, CA, USA) ion trap mass spectrometer equipped with an ESI source. Analysis was performed on a Hypersil Gold (Thermo Scientific, San Jose, CA, USA) C18 column (100 mm length; $2.1 \mathrm{~mm}$ i.d.; $1.9 \mu \mathrm{m}$ particle diameter, end-capped) and its temperature was maintained at $30^{\circ} \mathrm{C}$. The mobile phase for the separation of Retama raetam (Forssk.) Webb extracts constituents was composed of (A) acetonitrile and (B) $0.1 \%$ of formic acid $(v / v)$. The solvent gradient started with $5-40 \%$ of solvent (A) over $14.72 \mathrm{~min}$, from $40-100 \%$ over $1.91 \mathrm{~min}$, remaining at $100 \%$ for 2.19 more min before returning to the initial conditions. The flow rate was $0.2 \mathrm{~mL} \mathrm{~min}^{-1}$ and UV-Vis spectral data for all peaks were accumulated in the range of 200-500 nm while the chromatographic profiles were recorded at 280 and $340 \mathrm{~nm}$. Control and data 
acquisition of MS were carried out with the Thermo Xcalibur Qual Browser data system (Thermo Scientific, San Jose, CA, USA). Nitrogen above $99 \%$ purity was used and the gas pressure was $520 \mathrm{kPa}$ (75 psi). The instrument was operated in negative-ion mode with the ESI needle voltage set at $5.00 \mathrm{kV}$ and an ESI capillary temperature of $275^{\circ} \mathrm{C}$. The full scan covered the mass range from $m / z 100$ to 2000. CID-MS/MS and $\mathrm{MS}^{\mathrm{n}}$ experiments were simultaneously performed for precursor ions using helium as the collision gas with a collision energy of 25-35 arbitrary units.

Quantification of major compounds of each extract was also carried out and for that, calibration curves were obtained by the injection of known concentrations of different standard compounds, namely ginestin $\left(\mathrm{y}=11699.79 \mathrm{x}+33085.50 ; \mathrm{R}^{2}=0.999\right)$, quercetin-7-O-galactoside $(\mathrm{y}=10138.87 \mathrm{x}$ - 12806.00; $\left.R^{2}=0.995\right)$. Following a frequently adopted approach [47,48], when phenolic reference compounds were not available, the quantification was based on structurally related substances, and the results for each target phenolic compound were expressed in equivalents of the corresponding reference.

\subsection{Evaluation of Antioxidant Activities}

The antioxidant activity of $R$. raetam (Forssk.) Webb at the four seasonal stages were evaluated by distinct in vitro methods, as described in bellow. For that, extracts were obtained by magnetic stirring of $2.5 \mathrm{~g}$ dry powder in $25 \mathrm{~mL} 80 \%$ methanol for $30 \mathrm{~min}$. The mixtures were filtered through Whatman No. 4 filter paper and maintained at $4{ }^{\circ} \mathrm{C}$ until analysis [49].

\subsubsection{Total Antioxidant Capacity}

This assay is based on the reduction of $\mathrm{Mo}(\mathrm{VI})$ to $\mathrm{Mo}(\mathrm{V})$ by the extract and subsequent formation of a green phosphate $/ \mathrm{Mo}(\mathrm{V})$ complex at acid $\mathrm{pH}$ [50]. An aliquot $(0.1 \mathrm{~mL})$ of extracts was combined to $1 \mathrm{~mL}$ of reagent solution ( $0.6 \mathrm{M}$ sulfuric acid, $28 \mathrm{mM}$ sodium phosphate and $4 \mathrm{mM}$ ammonium molybdate). The tubes were incubated at $95{ }^{\circ} \mathrm{C}$ for $90 \mathrm{~min}$. After that, the mixture was cooled to room temperature and the absorbance of each solution was measured at $695 \mathrm{~nm}$ against a blank. The antioxidant capacity was expressed as $\mathrm{mg}$ gallic acid equivalent per gram dry weight $\left(\mathrm{mg} \mathrm{GAE} \cdot \mathrm{g}^{-1} \mathrm{DW}\right)$.

\subsection{2. $\mathrm{DPPH}^{\bullet}$ Scavenging Ability}

The radical scavenging activity of the extracts was measured using the $\mathrm{DPPH}^{\bullet}$ (1'1-diphenyl-2-picrylhydrazyl) method according to Hanato et al. [51]. For this, $1 \mathrm{~mL}$ of the extracts at various concentrations was mixed with $0.25 \mathrm{~mL}$ of a $\mathrm{DPPH}^{\bullet}$-methanolic solution $(0.2 \mathrm{mM})$ and allowed to react in the dark for $30 \mathrm{~min}$. Then, the absorbance of the resulting solution was read at $517 \mathrm{~nm}$. The antiradical activity was determined using Equation (2):

$$
\text { Inhibition }(\%)=\left[\left(\mathrm{A}_{0}-\mathrm{A}_{1}\right) / \mathrm{A}_{0}\right] \times 100
$$

where $\mathrm{A}_{0}$ is the absorbance of the control at $30 \mathrm{~min}$, and $\mathrm{A}_{1}$ is the absorbance of the sample at $30 \mathrm{~min}$. The antiradical activity was expressed as $\mathrm{IC}_{50}\left(\mathrm{mg} \cdot \mathrm{mL}^{-1}\right)$.

\subsection{3. $\mathrm{ABTS}^{\bullet+}$ Scavenging Activity}

$\mathrm{ABTS}^{\bullet+}$ was produced by the reaction between $5 \mathrm{~mL}$ of $7 \mathrm{mM}$ ABTS solution and $5 \mathrm{~mL}$ of $2.45 \mathrm{mM}$ potassium persulfate solution, stored in the dark for $16 \mathrm{~h}$. Before usage, this solution was diluted with ethanol to get an absorbance of $0.700 \pm 0.020$ at $734 \mathrm{~nm}$. The reaction mixture comprised $950 \mu \mathrm{L}$ of $\mathrm{ABTS}^{\bullet+}$ solution and $50 \mu \mathrm{L}$ of each sample at various concentrations. The mixture was homogenized and its absorbance was recorded after $6 \mathrm{~min}$ at $734 \mathrm{~nm}$ [52]. ABTS ${ }^{\bullet+}$ scavenging ability was expressed as $\mathrm{IC}_{50}\left(\mathrm{mg} \cdot \mathrm{mL}^{-1}\right)$. 


\subsubsection{Reducing Power}

The ability of the extracts to reduce $\mathrm{Fe}^{3+}$ was assayed by the method of Oyaizu [53]. Extracts $(1 \mathrm{~mL})$ were mixed with $2.5 \mathrm{~mL}$ of phosphate buffer $\left(0.2 \mathrm{M}\right.$, pH 6.6) and $2.5 \mathrm{~mL}$ of $\mathrm{K}_{3} \mathrm{Fe}(\mathrm{CN})_{6}(1 \%)$. After incubation at $50{ }^{\circ} \mathrm{C}$ for $20 \mathrm{~min}, 2.5 \mathrm{~mL}$ of trichloroacetic acid $(10 \%)$ was added and the mixture was centrifuged at $650 \times g$ for $10 \mathrm{~min}$. Finally, $2.5 \mathrm{~mL}$ of the upper layer was mixed with $2.5 \mathrm{~mL}$ of distilled water and $0.5 \mathrm{~mL}$ of aqueous $\mathrm{FeCl}_{3}(0.1 \%)$, then absorbance was measured at $700 \mathrm{~nm}$. Results were expressed as $\mathrm{EC}_{50}$ value $(\mathrm{mg} / \mathrm{mL})$ which is the effective concentration giving an absorbance of 0.5 and was obtained from linear regression analysis.

\subsubsection{Ferrous Ion Chelating Activity}

This activity was assessed as described by Zhao et al. [54]. Different concentrations of extracts were added to $0.05 \mathrm{~mL}$ of $\mathrm{FeCl}_{2}, 4 \mathrm{H}_{2} \mathrm{O}$ solution $(2 \mathrm{mM})$ and left for incubation at room temperature for $5 \mathrm{~min}$. Then, the reaction was initiated by adding $0.1 \mathrm{~mL}$ of ferrozine $(5 \mathrm{mM})$, and the mixture was adjusted to $3 \mathrm{~mL}$ with distilled water, shaken vigorously, and left at room temperature for $10 \mathrm{~min}$. Absorbance of the solution was then measured at $562 \mathrm{~nm}$. The inhibition of ferrozine- $\mathrm{Fe}^{2+}$ complex formation was calculated using Equation (1). Results are expressed as $\mathrm{EC}_{50}$, i.e., the efficient concentration corresponding to $50 \%$ ferrous iron chelating.

\subsection{6. $\beta$-Carotene Bleaching Test}

A modification of the method described by Koleva et al. [55] was employed. $\beta$-Carotene ( $2 \mathrm{mg})$ was dissolved in $20 \mathrm{~mL}$ chloroform and to $4 \mathrm{~mL}$ of this solution, linoleic acid ( $40 \mathrm{mg}$ ) and Tween 40 (400 mg) were added. Chloroform was evaporated under vacuum at $40^{\circ} \mathrm{C}$ and $100 \mathrm{~mL}$ of oxygenated ultra-pure water was added, then the emulsion was vigorously shaken. An aliquot $(150 \mu \mathrm{L})$ of the $\beta$-carotene/linoleic acid emulsion was distributed in each of the wells of 96-well plate and solutions of the test samples $(10 \mu \mathrm{L})$ were added. Three replicates were prepared for each sample. The plates were incubated at $50{ }^{\circ} \mathrm{C}$ for $120 \mathrm{~min}$. Absorbance was measured immediately $(\mathrm{t}=0 \mathrm{~min})$ and after incubation $(\mathrm{t}=120 \mathrm{~min}$ ) using a model EAR 400 plate reader (Labsystems Multiskan MS) at $470 \mathrm{~nm}$. The $\beta$-carotene bleaching ability of the extracts was determined using the Equation (3):

$$
\text { Inhibition }(\%)=[(\operatorname{As}(120)-\operatorname{Ac}(120)) /(\operatorname{Ac}(0)-\operatorname{Ac}(120))] \times 100
$$

where $\operatorname{Ac}(0)$ and $\operatorname{Ac}(120)$ are the absorbance values of the control at 0 and $120 \mathrm{~min}$, respectively, and $\mathrm{As}(120)$ is the sample absorbance at $120 \mathrm{~min}$. The results were expressed as $\mathrm{IC}_{50}$ values $\left(\mathrm{mg} \cdot \mathrm{mL}^{-1}\right)$.

\subsection{Evaluation of Antibacterial Activity}

The antimicrobial activity of $R$. raetam (Forssk.) Webb hydromethanolic extracts ( $2.5 \mathrm{~g}$ dry powder in $25 \mathrm{~mL} 80 \%$ methanol, $30 \mathrm{~min}$ ) at different grown stages was assessed by the agar disk diffusion method [56] against fourteen human pathogenic bacteria: Gram-positive cocci including Micrococcus luteus NCIMB 8166, Enterococcus faecalis ATCC 29212, Listeria monocytogenes ATCC 19115, Staphylococcus epidermidis CIP 106510, Bacillus cereus ATCC 14579, Staphylococcus aureus ATCC 25923, and Gram-negative bacteria including Aeromonas hydrophila ATCC 7566, Vibrio parahaemolyticus ATCC 17802, Vibrio cholerae non- $\mathrm{O}_{1}$ IPT, Vibrio alginolyticus ATCC 33787, Vibrio vulnificus ATCC 27962T, Salmonella typhimurium ATCC 1408, Pseudomonas aeruginosa ATCC 27853, Escherichia coli ATCC 85218. The bacterial strains were first grown on Muller Hinton medium at $37^{\circ} \mathrm{C}$ for $24 \mathrm{~h}$ prior to seeding onto the nutrient agar. One or several colonies of the indicator bacteria were transferred into API suspension medium (BioMérieux) and adjusted to the $0.5 \mathrm{McF}$ arland turbidity standard with a Densimat (BioMérieux). A sterile filter disc with $6 \mathrm{~mm}$ diameter (Whatman paper No 3) was placed on the infusion agar seeded with bacteria, and $10 \mu \mathrm{L}$ per disc of the extract $(300 \mathrm{mg} / \mathrm{mL})$ was added. The treated Petri dishes were incubated at $37^{\circ} \mathrm{C}$ for $24 \mathrm{~h}$. The antimicrobial activity was determined by measuring the zone of growth inhibition surrounding the discs. 


\subsection{Statistical Analysis}

For all plant parameters, three replicates were used. To determine the relative importance of grown stage on antioxidant compounds and biological activities, a two-way analysis of variance (ANOVA) was achieved for whole data, using the SAS system (1990) software, Version 6 (SAS Institute Inc., Cory, NJ, USA). Means were compared using the Duncan's multiple range test at the $p<0.05$ level, when significant differences were found. A principal component analysis (PCA) was performed to discriminate between different maturity stages on the basis of their fatty acid and phenolic composition. All analyses were performed by the "Statistica v 5.1" software [57].

\section{Conclusions}

The chemical composition, the phenolic profile, the antioxidant and antimicrobial activities of $R$. raetam (Forssk.) Webb during its growth cycle are reported. Based on our results, it is possible to infer that among the four studied stages, the vegetative one presented an interesting richness in vitamin C, polyunsaturated fatty acids, and polyphenols, consistent with the highest antioxidant and antimicrobial capacities. Thus, climatic conditions like high temperatures and light intensity found in summer and autumn (vegetative period) promote production of phenolic compounds, which is related to the high antioxidant activities throughout the development cycle. Therefore, the advised harvest time of $R$. raetam (Forssk.) Webb could be in the vegetative stage rather than the reproductive ones. Finally, these findings support the utilization of this plant in a large field of application including cosmetic, pharmaceutical, agro-alimentary, and biological defense.

Author Contributions: S.M.C. and R.K. planned and designed the experiments; M.S., H.F. and M.D.C. performed the experiments; M.S., H.F., M.D.C. and S.M.C. analyzed the data; M.S. and M.D.C. wrote the original draft and S.M.C. and R.K. reviewed and edited the manuscript. Finally, all the authors accepted the final version of the manuscript.

Funding: Funded by Centro2020, through FEDER and PT2020.

Acknowledgments: This work was supported by the Tunisian Ministry of Higher Education and Scientific Research (LR10CBBC02). Thanks are due to the University of Aveiro, FCT/MEC for the financial support to the QOPNA research Unit (FCT UID/QUI/00062/2013), through national funds and where applicable co-financed by the FEDER, within the PT2020 Partnership Agreement. Marcelo D. Catarino acknowledges FCT for financial support of his doctoral scholarship (PD/BD/114577/2016). Susana Cardoso thanks the research contract under the project AgroForWealth (CENTRO-01-0145-FEDER-000001).

Conflicts of Interest: The authors declare that they have no conflict of interest.

\section{References}

1. Yanishlieva, N.V.; Marinova, E.; Pokorny, J. Natural antioxidants from herbs and spices. Eur. J. Lipid Sci. Technol. 2006, 108, 776-793. [CrossRef]

2. Ângela, S.F.; Barros, F.L.; Carvalho, A.M.; Ferreira, I.C.F.R. Lipophilic and hydrophilic antioxidants, lipid peroxidation inhibition and radical scavenging activity of two Lamiaceae food plants. Eur. J. Lipid Sci. Technol. 2010, 112, 1115-1121.

3. Hamana, N.; Longoa, E.; Schiraldib, A.; Scampicchioa, M. Radical scavenging activity of lipophilic antioxidants and extra-virgin olive oil by isothermal calorimetry. Thermochim. Acta 2017, 658, 1-6. [CrossRef]

4. Correia, R.T.; Borges, K.C.; Medeiros, M.F.; Genovese, M.I. Bioactive compounds and phenolic-linked functionality of powdered tropical fruit residues. Food Sci. Technol. Int. 2012, 6, 539-547. [CrossRef] [PubMed]

5. Lü, J.M.; Lin, P.H.; Yao, Q.; Chen, C. Chemical and molecular mechanisms of antioxidants: Experimental approaches and model systems. J. Cell. Mol. Med. 2010, 14, 840-860. [CrossRef] [PubMed]

6. Alam, M.N.; JahanBristi, N.; Rafiquzzaman, M. Review on in vivo and in vitro methods evaluation of antioxidant activity. Saudi Pharm. J. 2013, 21, 143-152. [CrossRef] [PubMed]

7. Lisiewska, Z.; Kmiecik, W.; Korus, A. Content of vitamin C, carotenoids, chlorophylls and polyphenols in green parts of dill (Anethum graveolens L.) depending on plant height. J. Food Compos. Anal. 2006, 19, $134-140$. [CrossRef] 
8. Liu, C.Z.; Guo, C.; Wang, Y.C.; Ouyang, F. Effect of light irradiation on hairy root growth and artemisinin biosynthesis of Artemisia annua. Process. Biochem. 2002, 38, 581-585. [CrossRef]

9. Xie, B.D.; Wang, H.T. Effects of light spectrum and photoperiod on contents of flavonoid and terpene in leaves of Ginkgo biloba L. J. Nanjing Fore. Univ. Nat. Sci. Ed. 2006, 30, 51-54.

10. Briskin, D.P.; Gawienowski, M.C. Differential effects of light and nitrogen on production of hypericins and leaf glands in Hypericum perforatum. Plant Physiol. Biochem. 2001, 39, 1075-1081. [CrossRef]

11. Edziri, H.; Mastouri, M.; Mahjoub, M.A.; Mighri, Z.; Mahjoub, A.; Verschaeve, L. Antibacterial, Antifungal and Cytotoxic Activities of Two Flavonoids from Retama raetam Flowers. Molecules 2012, 17, 7284-7293. [CrossRef] [PubMed]

12. Djeddi, S.; Karioti, A.; Yannakopoulou, E.; Papadopoulosn, K.; Chatter, R.; Skaltsa, H. Analgesic and Antioxidant Activities of Algerian Retama raetam (Forssk.) Webb \& Berthel Extracts. Rec. Nat. Prod 2013, 7, 169-176.

13. El Hamrouni, A. Conservation des zones humides littorales et des ecosystèmes côtiers du Cap-bon. Rapport de diagnostic des sites partie relative à la flore et la végétation. In Rapport De Diagnostic Des Sites, Partie Relative Aux Mammifères; Agence de Protection et d'Amenagement du Littoral: Tunisie, Tunisia, 2001; pp. 1-33.

14. Maghrani, M. Acute diuretic effect of aqueous extract of Retama raetam in normal rats. J. Ethnopharmacol. 2005, 99, 31-35. [CrossRef] [PubMed]

15. Awen, B.Z.; Unnithan, C.R.; Ravi, S.; Kermagy, A.; Sasikumar, J.M.; Khrbash, A.S.; Ekreem, W.L. Essential oils of Retama raetam from Libya: Chemical composition and antimicrobial activity. Nat. Prod. Res. 2011, 9, 927-933. [CrossRef] [PubMed]

16. Edziri, H.; Mastouri, M.; Cherai, I.; Aouni, M. Chemical composition and antibacterial, antifungal and antioxidant activities of the flower oil of Retama raetam (Forssk.) Webb from Tunisia. Nat. Prod. Res. 2010, 9 , 789-796. [CrossRef] [PubMed]

17. Saada, M.; Falleh, H.; Jalleli, I.; Snoussi, M.; Ksouri, R. Phenolic profile, biological activities and fraction analysis of the medicinal halophyte Retama raetam. S. Afr. J. Bot. 2014, 94, 114-121.

18. Howard, L.R.; Talcott, S.T.; Brenes, C.H.; Villalon, B. Changes in Phytochemical and Antioxidant Activity of Selected Pepper Cultivars (Capsicum Species) as influenced by maturity. J. Agric. Food Chem. 2000, 48, 1713-1720. [CrossRef]

19. Hopkins, W.G.; Évrard, C.M. Physiologie Végétale; De Boeck Supérieur: Paris, France, 2003; pp. 1-532.

20. Richard, D.; Kefi, K.; Barbe, U.; Bausero, P.; Visioli, F. Polyunsaturated fatty acids as antioxidants. Pharmacol. Res. 2008, 57, 451-455. [CrossRef] [PubMed]

21. Nelson, M.M.; Phleger, C.F.; Nichols, P.D. Seasonal lipid composition in macroalgae of the northeastern Pacific Ocean. Bot. Mar. 2002, 45, 58-65. [CrossRef]

22. Los, D.; Mironov, K.; Allakhverdiev, S. Regulatory role of membrane fluidity in gene expression and physiological functions. Photosynth. Res. 2013, 116, 489-509. [CrossRef] [PubMed]

23. Gallie, D.R. L-Ascorbic Acid: A Multifunctional Molecule Supporting Plant Growth and Development. Scientifica 2012, 2013, 795964. [CrossRef] [PubMed]

24. Smirnoff, N.; Wheeler, G.L. Ascorbic acid in plants: Biosynthesis and function. Crit. Rev. Biochem. Mol. Biol. 2000, 35, 291-314. [CrossRef] [PubMed]

25. Gallie, D.R. The role of L-ascorbic acid recycling in responding to environmental stress and in promoting plant growth. J. Exp. Bot. 2013, 64, 433-443. [CrossRef] [PubMed]

26. Mattioli, R.; Falasca, G.; Sabatini, S.; Altamura, M.M.; Costantino, P.; Trovato, M. The proline biosynthetic genes P5CS1 and P5CS2 play overlapping roles in Arabidopsis flower transition but not in embryo development. Physiol. Plant. 2009, 137, 72-85. [CrossRef] [PubMed]

27. Lehmann, S.; Funck, D.; Szabados, L.; Rentsch, D. Proline metabolism and transport in plant development. J. Amino Acids 2010, 39, 949-962. [CrossRef] [PubMed]

28. Kale, V.S. Variable Rates of Primary and Secondary Metabolites during Different Seasons and Physiological Stages in Convolvulus, Datura and Withania. Asian J. Exp. Biol. Sci. 2010, 10, 50-53.

29. Ksouri, R.; Megdiche, W.; Falleh, H.; Trabelsi, N.; Boulaaba, M.; Smaoui, A.; Abdelly, C. Influence of biological, environmental and technical factors on phenolic content and antioxidant activities of Tunisian halophytes. C. R. Biol. 2008, 331, 865-873. [CrossRef] [PubMed] 
30. Parr, A.J.; Bolwell, P.A.J. Phenols in the plant and in man: The potential for possible nutritional enhancement of the diet by modifying the phenols content or profile. J. Sci. Food Agric. 2000, 80, 985-1012. [CrossRef]

31. Combris, P.; Amiot-Carlin, M.J.; Caillavet, F.; Causse, M.; Dallongeville, J.; Padilla, M.; Renard, C.; Soler, L.G. Les Fruits et Légumes dans l'Alimentation: Enjeux et Déterminants de la Consommation; Expertise Scientifique Collective INRA: Paris, France, 2007.

32. Toor, R.K.; Savage, G.P.; Lister, C.E. Seasonal variations in the antioxidant compositions of greenhouse grown tomatoes. J. Food Compos. Anal. 2006, 19, 1-10. [CrossRef]

33. Touati, R.; Santos, S.A.O.; Rocha, S.M.; Belhamel, K.; Silvestre, A.J.D. Phenolic composition and biological prospecting of grains and stems of Retama sphaerocarpa. Ind. Crops Prod. 2017, 95, 244-255. [CrossRef]

34. León-González, A.J.; Navarro, I.; Acero, N.; Muñoz Mingarro, D.; Martín -Cordero, C. Genus Retama: A review on traditional uses, phytochemistry, and pharmacological activities. Phytochem. Rev. 2018, 17, 701-731. [CrossRef]

35. González-Mauraza, N.H.; León-González, A.J.; Espartero, J.L.; Gallego-Fernández, J.B.; Sánchez-Hidalgo, M.; Martin-Cordero, C. Isolation and quantification of pinitol, a bioactive cyclitol, in Retama spp. Nat. Prod. Commun. 2016, 11, 405-406. [PubMed]

36. Xu, W.H.; Adnan, J.A.R.; Muhammad, Y.; Mohammad, S.A.; Shabana, I.K.; Ikhlas, A.K. Two New Flavonoids from Retama raetam. Helv. Chim. Acta. 2015, 98, 561-568. [CrossRef]

37. Meot-Duros, L.; Le Floch, G.; Magné, C. Radical scavenging, antioxidant and antimicrobial activities of halophytic species. J. Ethnopharmacol. 2008, 116, 258-262. [CrossRef] [PubMed]

38. Scalbert, A.; Johnson, I.T.; Saltmarsh, M. Polyphenols: Antioxidants and beyond. Am. J. Clin. Nutr. 2005, 81, 215S-217S. [CrossRef] [PubMed]

39. Bensaci, H.; Sekhri, L.; Atmani, A.; Tabchouche, A. A qualitative phytochemical analysis and a comparative study of the antibactrial activity of Retama stalks (raetam). Orient. J. Chem. 2016, 32, 313-319. [CrossRef]

40. Hammouche-Mokranea, N.J.; León-Gonzálezb, A.; Navarroc, I.; Boulilaa, F.; Benallaouad, S.; Martín-Corderob, C. Phytochemical Profile and Antibacterial Activity of Retama raetam and R. sphaerocarpa cladodes from Algeria. Nat. Prod. Commun. 2017, 12, 1857-1860.

41. Nonier, M.F.; De Gaulejac, N.V.; Vivas, N.; Vitry, C. Characterization of carotenoids and their degradation products in oak wood. Incidence on the flavour of wood. C. R. Chim. 2004, 689-698. [CrossRef]

42. Megdiche Ksouri, W.; Chaouachi, F.; M’Rabet, R.; Medini, F.; Zaouali, Y.; Trabelsi, N.; Ksouri, R.; Noumi, E.; Abdelly, C. Antioxidant and antimicrobial properties of Frankenia thymifolia Desf. fractions and their related biomolecules identification by gas chromatography/mass spectrometry (GC/MS) and high performance liquid chromatography (HPLC). J. Med. Plants Res. 2011, 5, 5754-5765.

43. Kampfenkel, K.; Van Montau, M.; Inze, D. Extraction and determination of ascorbate and dehydrascorbate from plant tissue. Anal. Biochem. 1995, 225, 165-167. [CrossRef] [PubMed]

44. Bates, L.S.; Waldren, R.P.; Teare, I.D. Rapid determination of the free proline in water stress studies. Plant Soil 1973, 39, 205-208. [CrossRef]

45. Dewanto, V.; Wu, X.; Adom, K.K.; Liu, R.H. Thermal processing enhances the nutritional value of tomatoes by increasing total antioxidant activity. J. Agric. Food Chem. 2002, 50, 3010-3014. [CrossRef] [PubMed]

46. Catarino, M.D.; Silva, A.M.S.; Saraiva, S.C.; Sobral, A.J.F.N.; Cardoso, S.M. Characterization of phenolic constituents and evaluation of antioxidant properties of leaves and stems of Eriocephalus africanus. Arab. J. Chem. 2018, 11, 62-69. [CrossRef]

47. Perestrelo, R.; Lu, Y.; Santos, S.A.O.; Silvestre, A.J.D.; Neto, C.P.; Câmara, J.S.; Rocha, S.M. Phenolic profile of

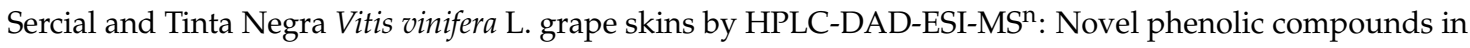
Vitis vinifera L. grape. Food Chem. 2012, 135, 94-104. [CrossRef]

48. Määttä-Riihinen, K.R.; Kamal-Eldin, A.; Törrönen, A.R. Identification and quantification of phenolic compounds in berries of Fragaria and Rubus species (family rosaceae). J. Agric. Food Chem. 2004, 52, 6178-6187. [CrossRef] [PubMed]

49. Falleh, H.; Ksouri, R.; Chaieb, K.; Karray-Bouraoui, N.; Trabelsi, N.; Boulaaba, M.; Chedly, A. Phenolic composition of Cynara cardunculus L. organs and their biological activities. C. R. Biol. 2008, 331, 372-379. [CrossRef] [PubMed]

50. Prieto, P.; Pineda, M.; Aguilar, M. Spectrophotometric quantitation of antioxidant capacity through the formation of a phosphomolybdenum complex: Specific application to the determination of vitamin E. Anal. Biochem. 1999, 269, 337-341. [CrossRef] [PubMed] 
51. Hanato, T.; Kagawa, H.; Yasuhara, T.; Okuda, T. Two new flavonoids and other constituents in licorice root their relative astringency and radical scavenging effect. Chem. Pharm. Bull. 1988, 36, 1090-1097.

52. Re, R.; Pellegrini, N.; Proteggente, A.; Pannala, A.; Yang, M.; Rice-evans, C. Antioxidant activity applying an improved ABTS $^{\bullet+}$ radical decolorization assay. Free Radic. Biol. Med. 1999, 26, 1231-1237. [CrossRef]

53. Oyaizu, M. Studies on products of browning reaction: Antioxidative activity of products of browning reaction. Jpn. J. Nutr. Diet. 1986, 44, 307-315. [CrossRef]

54. Zhao, H.; Dong, J.; Lu, J.; Chen, J.; Li, Y.; Shan, L.; Lin, Y.; Fan, W.; Gu, G. Effect of extraction solvent mixtures on antioxidant activity evaluation and their extraction capacity and selectivity for free phenolic compounds in Barely (Hordeum vulgare L.). J. Agric. Food. Chem. 2006, 54, 7277-7286. [CrossRef] [PubMed]

55. Koleva, I.I.; Teris, A.B.; Jozef, P.H.; Linssen, A.G.; Lyuba, N.E. Screening of plant extracts for antioxidant activity: A comparative study on three testing methods. Phytochem. Anal. 2002, 13, 8-17. [CrossRef] [PubMed]

56. Bagamboula, M.; Uyttendaele, J.; Debevere, M. Inhibitory effect of thyme and basil essential oils, carvacrol, thymol, estragol, linalool and p-cymene towards Shigella sonnei and S. flexneri. Food Microbiol. 2003, 21, $33-42$. [CrossRef]

57. Statistica. In Windows (Computer Program Electronic Manual); StatSoft, Inc.: Tulsa, OK, USA, 1998.

Sample Availability: Samples of the compounds are available from Mariem Saada and Susana M. Cardoso authors.

(C) 2018 by the authors. Licensee MDPI, Basel, Switzerland. This article is an open access article distributed under the terms and conditions of the Creative Commons Attribution (CC BY) license (http:/ / creativecommons.org/licenses/by/4.0/). 